\title{
Anne Duncan
}

\section{'Mime and Metatheatre'}

Alone among the theatrical genres of the ancient Greco-Roman world, mime was performed unmasked, and by female as well as male actors. These two facts are probably linked.

At the risk of belabouring the obvious, I would like to linger for a moment over the logic of masked drama in the ancient world. Regular Greek drama that is, the scripted, institutionalized drama of comedy, tragedy, and satyr play - employed masks. There are two reasons conventionally advanced by scholars to explain the custom of masked acting in the ancient world; we feel this convention needs explanation, since we do not share it. One reason often put forth is ritual: masked acting maintained the ritual connection with the worship of Dionysos, which employed masks as well. ${ }^{1}$ The other reason is practical: masks enabled spectators sitting far away from the stage to recognize different characters. ${ }^{2}$ A third reason that is less often discussed is ideological: masks made it 'possible' for male actors to play female characters; that is, masked acting naturalized male actors playing female characters. Greek actors were exclusively male, presumably, because the high degree of sexual segregation in Classical Athens and the emphasis on female modesty throughout ancient Greek culture made it seem impossible for women to perform onstage. This ideology seems to have carried over into Roman culture, with its proliferation of dramatic genres, although the reasoning for the ban on female actors in either culture is never made explicit. ${ }^{3}$

1 Jane Ellen Harrison and the 'Cambridge School' were ultimately behind this view of tragedy as ritual; see discussion in Csapo/Miller (2007) 1-38; Wise (1998) 61-62. Most scholars these days who discuss the religious connotations of dramatic masks do so in a more cautious way than Harrison and her contemporaries; see Wiles (2007) 1-12; Lada-Richards (1997) 96; Cartledge (1997) 8; Easterling (1997a) 37; 45; 49-52; Green (1994) 77-80. Scullion (2002b) 116-117 denies any ritual component to the Greek theatrical mask. On masks, see also Taplin pp. 24-27 and Paillard in this volume, pp. 74-76.

2 Taplin (2003) 14-15; Wiles (2007) 9-11; see also Wiles (1991) 132-133 on masked acting of Plautus' comedies in Republican Rome, which he argues was carried over from Greek traditions.

3 Interestingly, the ancient silence on the reason for all-male acting troupes (and choruses) has produced a similar silence in modern scholarship. Some scholars acknowledge in passing that acting was restricted to men, but seem to accept it as an inevitable consequence of Athenian gender ideology; see, e.g., Storey/Allan (2014) 45-46; Lightfoot (2002) 212; Bassi (1998) 141; Cartledge (1997) 21. Zeitlin (1996) 341-374 remains a classic statement of the influence of the feminine on Classical Athenian tragedy, but does not discuss masking per se, or why exactly women

○ Open Access. (C) 2021 Anne Duncan, published by De Gruyter. (cc) BY This work is licensed under the Creative Commons Attribution 4.0 International License.

https://doi.org/10.1515/9783110716559-012 
For whatever reason, however, the Greco-Roman genre of mime departed from the norm of all-male theatrical troupes and employed female as well as male actors. With origins perhaps in fifth century Greece, mime spread throughout the Hellenistic Greek world, including Egypt, Sicily, and Magna Graecia, where it was likely influenced by native Italian dramatic forms to create the sprawling hybrid genre enjoyed throughout the Greco-Roman world. ${ }^{4}$ Mime seems to have taken off in popularity in Roman-controlled territories during the late Republican period, when traditional comedy and tragedy, as well as a welter of other dramatic genres, were still being performed regularly. ${ }^{5}$ In a world where most drama was performed by male actors who wore masks, in part, to be able to play female characters 'convincingly,' it seems that a real woman performing had to be unmasked to display her realness to the spectators. Mime actresses (mimae) were thus marked out as different by their apparent lack of theatrical artifice. They were also marked out, as all actors in the Roman world were, by their infamis social status: denied most citizen rights, and subject to corporal punishment, like slaves - 'legally branded as disgraceful,' as Edwards says. ${ }^{6}$

It may seem contradictory to begin a discussion of metatheatre with a consideration of a lack of theatrical artifice, but such was the nature of mime: contrary to 'establishment' or 'authorized' theatre, even as the different genres were performed virtually side-by-side. Mime was contrary to the traditional dramatic genres in that it encompassed a much broader range of subjects (from scripted tragic-style dramas to improvised comic burlesques of Christian sacraments), was performed in a much broader range of venues (from private homes to marketplaces), eschewed traditional conventions of decorum and dramatic restraint, and, of course, put forth female performers for men to gaze at. In this chapter, I will consider whether the sheer fact of women performing unmasked in mime functioned metatheatrically, as a way of calling attention to the theatrical

were excluded from performing. Hov (2015) 130-134 surveys histories of Western theatre, noting that they tend to ignore or downplay ancient female performers, especially when those histories focus on dramatic textual traditions rather than evidence from material culture.

4 On the history of mime, see Tsitsiridis (2011) 213-214; Panayotakis (2010) 1-2; 16-32; Csapo/ Slater (1995) 369-78; Beacham (1991) 129-39. The scattered 'literary' mime authors in the tradition, such as the fifth-century BC Sicilian Sophron and the third-century BC Alexandrians Herodas and Theocritus, are part but not all of the origin story of mime, as is the performance of a mime (including a female mime performer) in Xenophon's Symposium, which was written during the fourth century but set in the fifth century.

5 Panayotakis (2010) 26-27 discusses the reciprocal influence of comic mime and fabula palliata on each other in the second c. BC; Manuwald (2010) 1-15 gives an overview of Roman dramatic genres, known playwrights, and dates.

6 Edwards (1993) 123. See also French (1998) 296-99; Richlin (1992) 99-100. 
artifice of conventional, all-male, masked drama. I will also consider whether there were other ways in which mime actresses compensated for their relative exposure by concealing other parts of themselves.

We might think about the potential metatheatricality of mime actresses in the context of two fragmentary mime scripts in Koine that have come to us from Egypt on the two sides of one piece of papyrus (P.Oxy.413). On the verso is the 'Charition mime' and on the recto, the 'jealous mistress mime,' both of which seem to have featured lead female roles. ${ }^{7}$ Both of these scripts have strong echoes of more 'literary' Greek texts, such as tragedy and the ancient novel, which featured prominent female characters.

The 'Charition mime' concerns a Greek woman, Charition, who is being held captive by a wicked king in India. What has survived on the papyrus is the escape scene, in which Charition has taken sanctuary in the temple of an Indian goddess, while her brother has arrived on a ship with other Greeks, including a fool, in order to rescue her. The ship's captain gets drunk, however, and the temple is surrounded by Indians. The fool farts so loudly that the noise and stench scatter the barbarians to a nearby river. The Amazon-like wives and daughters of the Indians return from a hunt and surround the temple and the fool farts again to disperse them. (These farts are clearly indicated in the stage directions on the papyrus.) The fool urges Charition to steal the temple offerings during their escape, but Charition refuses, saying that it is not right to do so. The Indians reappear after bathing in the river and the brother orders the fool to give them unmixed wine. The fool gets drunk along with the Indian King and the Chorus of Indian women, who speak in invented 'Indian'. They all dance, and the Indian king sings a solo (in perfect, metrical Greek verse). Then the king and the chorus all pass out, and the Greeks tie them up. Charition comes back out of the temple, where she remained during the festivities. Her brother orders the Greeks to set sail and all the Greeks escape. During their escape, Charition prays to the Indian goddess to save them from their pursuers.

The plot of the 'Charition mime' is reminiscent of Euripides' Helen and Iphigenia among the Taurians, in that it concerns a Greek woman, held captive by a wicked foreign king, who escapes with a party of rescuing Greeks by sea. The drunk scene recalls the Cyclops episode in Homer's Odyssey and Euripides' Cyclops. Judging by the number of characters and other textual cues, the mime was a fairly elaborate, tightly-choreographed production with a chorus of 'Indian' women and an 'Indian' king speaking an invented, nonsensical 'Indian'

7 Texts in Rusten/Cunningham (2002) 376-400. On the Charition, see also Skotheim in this volume. 
language, as well as music (drums are indicated in the stage directions), sound effects (including the farts from the fool) and many props. The presence of stage directions and musical notations on the papyrus indicates that it was a working script of some kind. ${ }^{8}$ Charition is presented as a respectable woman in this mime: she argues against stealing objects from a temple, does not get drunk, and behaves herself throughout. The chorus of 'Indian' women, on the other hand, may have been presented as exotic stereotypes: they threaten men with weapons, they speak and drink in public and bathe in rivers with men. To a Greek way of thinking, they are shameless - like the chorus of (male) satyrs in Euripides' Cyclops.

While Charition behaves with almost tragic decorum in what survives of this mime, the characters around her vigorously and enthusiastically undermine that decorum. The ship's captain, the fool, and the 'Indians' get drunk, and the fool farts - and talks about farting - constantly. It is as if Charition is a tragic heroine out of one of Euripides' escape-dramas, plunked down into the midst of an especially raunchy comedy or satyr play. The contrast between her behaviour and that of the other characters emphasizes the parody of tragedy, much like the scene in Aristophanes' Thesmophoriazusae where Euripides and his relative pretend to be Perseus and Andromeda from Euripides' Andromeda while the Scythian archer, who does not understand their tragic allusions, keeps breaking the mood with crude remarks. ${ }^{9}$ The mime sets up Charition as a representative of tragedy in a metatheatrical clash of genres.

The 'jealous mistress mime' on the other side of this papyrus is a little harder to reconstruct, because the version of the script written on the page seems to have been the working copy of the archimima; it has only her lines for several scenes, but ends with a group scene in which the other characters' lines are written but not hers. ${ }^{10}$ The mime seems to have concerned the mistress of a household devising a plot to frame a male slave for rape because he spurned her sexual advances, a story which has many parallels with Euripides' Hippolytus.

From what has survived of the script, the plot of the mime appears to be as follows: the jealous mistress desires to have sex with her slave Aesopus, but he is in love with Apollonia, another slave in the household. The mistress orders slaves to take the lovers into the forest, bind them to trees, and kill them. Apollonia is discovered inside the house, and the mistress orders her slaves to find

8 See discussion in Tsitsiridis (2011) 187-189; 198-206; Webb (2008) 108; 110-111; 129; Panayotakis (2006) 129; Andreassi (2001) 88-158.

9 Farmer (2017) 182-88 discusses the parodic and metatheatrical elements of this scene in Thesm. On this scene, see also Vespa in this volume, p. $197 \mathrm{ff}$.

10 Tsitsiridis (2011) 191-97. 
Aesopus and bring him back dead. When he is brought back, apparently but not actually dead, the mistress laments over his supposedly dead body; her slave Malacus comforts her and possibly becomes aroused, an assumption based on his joke name. ${ }^{11}$ The mistress tells Malacus that she has decided to poison first her elderly husband and then the entire household and to sell off the property. At some point, Apollonia is also brought onstage, apparently but not actually dead either. When the mistress sees the (supposed) dead body of Apollonia alongside that of Aesopus, she asks the parasite to summon her husband and prepares to poison him. Malacus enters, carrying the poisoned wine, but Spinther, a loyal slave, switches the poisoned wine with regular wine. When the parasite deliberately drinks the wine (which the mistress believes is the wine she poisoned), she panics and has him carried inside so that she can find out what happens to him before her husband does. Spinther and the parasite come back onstage, while the mistress and the old master enter the house. The household slaves are all in on the plan to fool the mistress and Malacus, so when the two of them come back onstage, the parasite tells the mistress that her husband is dead, and she rejoices that her plan has worked. Then the slaves bring the (supposedly) dead body of the old master onstage, and someone (it is unclear who) mourns him, but the old master unexpectedly rises up and beats Malacus. When the old master sees the (supposedly) dead bodies of Aesopus and Apollonia, the other slaves reassure him that they are not really dead either, and presumably at some point they revive too. ${ }^{12}$

The plot of the 'jealous mistress mime' is one variant of the famous (or infamous) adultery mime, ${ }^{13}$ but it is also reminiscent of Euripides' Hippolytus, as well as several literary accounts of slave-owning women who feel unrequited passion for their slaves (and usually come to a bad end), such as Herodas's $M i$ miamb 5, the Life of Aesop, and Book 10 of Apuleius' Golden Ass. ${ }^{14}$ The complicated plot involving attempted murder and people who feign death evokes the almost soap-operatic plots of several Greek novels, including the Ephesian Tale of Xenophon and the Aethiopian Story of Heliodorus. ${ }^{15}$

11 Tsitsiridis (2011) 190.

12 See discussion in Tsitsiridis (2011) 189-197, who argues that it is the mistress who pretends to mourn the old master in the final scene, rather than Spinther or the parasite, as others have argued. See also Webb (2008) 109-112; 135; Panayotakis (2006) 129; Andreassi (2001) 88-158.

13 See $n$. 19 below.

14 Mimiamb 5 was probably titled ZН $\Lambda$ ОТҮПО , even though the word is not used in the text: Tsitsiridis (2011) 206; Fantham (1986) 52. Cf. the story of Potiphar's wife and Joseph in Genesis 39.1-20.

15 Tsitsiridis (2011) 206-09. 
The role of the jealous mistress appears to have been a starring villain role, much like Phaedra or Clytemnestra or Medea in tragedy. Unlike Phaedra or Clytemnestra or Medea, however, the jealous mistress character uses obscene language twice in the extant fragments of the mime, both times in the context of her own sexuality:

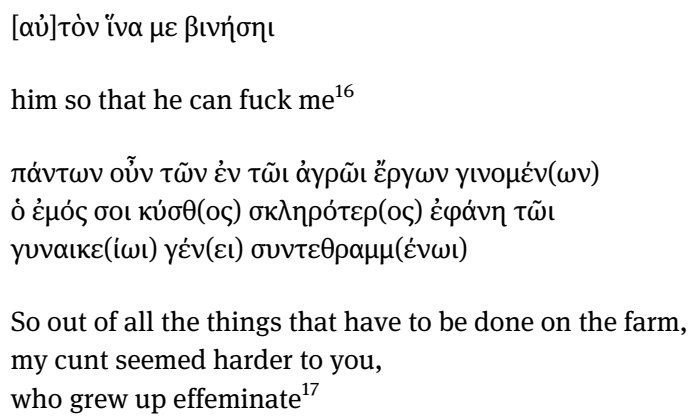

This sort of language was unthinkable in tragedy; it is far more reminiscent of Old Comedy, a genre which, of course, made great use of metatheatrical parodies of tragedy. Indeed, the plot of this mime - a foul-mouthed Phaedra lusting after her (theoretically accessible) slave, rather than her (tragically taboo) stepson seems to be a comic burlesque of tragedy. It removes the tragic elements (decorous language, elite social status, the machinations of the gods) to reveal a squalid truth: the woman is an immoral criminal. Put another way, the mime removes the female mask, elaborate robes, and tasteful obfuscation of traditional tragic language to reveal a real woman saying and doing nasty things.

Many female characters in the P.Oxy.413 scripts and in other extant mime script fragments, such as those of Decimus Laberius, display stereotypical negative female traits: lechery, greed, deceitfulness, drunkenness. ${ }^{18}$ For example, Laberius' The Seamstress (Belonistria) contained the lines:

domina nostra privignum suum

amat efflictim

Our mistress is passionately in love

with her stepson. ${ }^{19}$

16 All translations are mine.

17 See Webb (2008) 109 and n. 71.

18 Panayotakis (2010) 6-7 and (2006) 124-125 cautions against reading mime scripts for real women's voices, noting that female characters in mime are 'as conventional and artificial in their behaviour as their female counterparts in the other genres of popular theatre'.

19 Panayotakis (2010) 142-146. 
Both the 'jealous mistress' mime from P.Oxy.413 and Laberius' The Seamstress are scripted examples of the adultery mime, which we know could also be performed entirely improvised. Webb has summarized the adultery mime's plot succinctly: 'A clever young wife and her lover are surprised by her slow-witted husband. ${ }^{20}$ Endless variations were possible: sometimes the lover is discovered by the husband; sometimes the wife successfully conceals him from her husband. Because of its simplicity (only three actors were required, and minimal props), as well as its universal appeal, the adultery mime enjoyed lasting popularity across the GrecoRoman world. Undoubtedly, it played a role in associating mimae with shameless behavior.

If audiences tended to conflate mimae with the stereotypical female characters they played, this might explain why so many of our ancient sources on mimae assume and imply that they are prostitutes. Cicero is a veritable gold mine of slut-shaming digs against mime actresses. In a private letter to a friend, he reveals his consternation at attending a dinner party given in a respectable equestrian's house and seeing the mima Cytheris reclining in a place of honour just below the host (Cic. Ad fam. 9.26.1-2). ${ }^{21}$

accubueram hora nona, cum ad te harum exemplum in codicillis exaravi. 'ubi?' apud Volumnium Eutrapelum, et quidem supra me Atticus, infra Verrius, familiares tui. miraris tam exhilaratam esse servitutem nostrum? quid ergo faciam? (te consulo, quid philosophum audis) angar, excruciem me? quid adsequar? deinde quem ad finem? 'vivas,' inquis, 'in litteris.' an quicquam me aliud agere censes aut posse vivere, nisi in litteris viverem? sed est earum etiam non satietas sed quidam modus; a quibus cum dicessi, etsi minimum mihi est in cena

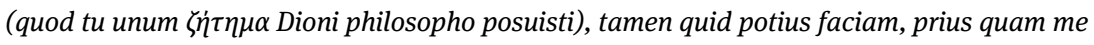
dormitum conferam, non reperio. audi reliqua: infra Eutrapelum Cytheris accubuit. 'in eo igitur' inquis 'convivio Cicero ille, 'quem aspectabant, cuius ab os Graii ora obvertebant sua?' non me hercule suspicatus sum illam adfore. sed tamen ne Aristippus quidem ille Socraticus erubuit, cum esset obiectum habere eum Laida. 'habeo,' inquit, 'non habeor a Laide' (Graece hoc melius; tu, si voles, interpretabere); me vero nihil istorum ne iuvenem quidem movit umquam, ne nunc senem; convivio delector; ibi loquor quod in solum, ut dicitur, et gemitum in risus maximos transfero.

I had been reclining at the ninth hour when I wrote a copy of this to you on tablets. 'Where?' At Volumnius Eutrapelus', and indeed, Atticus is seated above me, Verrius below me, friends of yours. Are you astonished that our slavery has been made so cheerful? What, then, should I do? (I ask your advice, since you listen to a philosopher). Should I be troubled, should I torture myself? What should I pursue? Then for how long? 'Live in

20 Webb (2008) 105. On the adultery mime, see Panayotakis (2010) 10-11 and (2006) 128; Webb (2008) 105-112; Fountoulakis (2000) 143; Fantham (1989) 158; Reynolds (1946).

21 On Roman banquet seating, see Plut. Mor. 619a-b and f; Dunbabin (2003) 22-23; 39-40 and fig.21; D’Arms (1999) 313-14; Dunbabin (1991) 122-128. 
your books,' you say. Do you think that I am doing anything else, or that I can live if I did not live in my books? But of them there is not even an abundance, but a certain measure; when I departed from these people, although I have very little interest in dinner (which is one problème you posed to the philosopher Dio), nevertheless what I should rather do, before I take myself to bed, I cannot come up with. Listen to the rest: Cytheris reclined below Eutrapelus. You say, 'Was the Cicero, 'whom they gazed at earnestly, toward whose face Greeks turned their own faces,' at this banquet?' By Hercules, I did not suspect that she would be there. But nevertheless, not even that famous Socratic Aristippus blushed when it was brought up that he kept Lais. He said, 'I have Lais, I am not had by Lais' (this is better in Greek; you will translate if you wish). But nothing of those sorts of things ever excited me, neither as a youth, nor now as an old man. I am delighted by a banquet; there I say what comes into the sole, as it is said, and I turn a groan into the biggest laughs.

In this letter, Cicero takes pains to establish that he did not attend the party in the hopes of seeing Cytheris, and that he thought her presence there was distasteful, but that he was equal to the situation. His quotation from the philosopher Aristippus serves three functions. It compares the actress Cytheris to Lais, a famous Greek prostitute. ${ }^{22}$ It aligns Cicero with grammatical and sexual activity ('I have Lais'), the proper domain of a Roman man, rather than passivity ('I am had by Lais'). Finally, it connects the letter writer and his addressee in an affirmation of shared, exclusive, elite status by signaling that the Latin quotation is originally a Greek quotation, which they both can read.

Cicero plays on the same class snobbery in his public speech prosecuting Verres for corruption, alleging that Verres forced the respectable wives of his army officers to mingle socially against their will with his girlfriend, the mima Tertia (Cic. 2 Verr. 5.12.31): ${ }^{23}$

huc Tertia illa perducta per dolum atque insidias ab Rhodio tibicine maximas in istius castris effecisse dicitur turbas, cum indigne pateretur uxor Cleomenis Syracusani, nobilis mulier, itemque uxor Aeschrionis, honesto loco nata, in conventum suum mimi Isidori filiam venisse. iste autem Hannibal, qui in suis castris virtute putaret oportere non genere certari, sic hanc Tertiam dilexit ut eam secum ex provincia deportaret.

This Tertia, having been led on by a trick and by the greatest plots away from her Rhodian flute-player, is said to have created a great disturbance in that camp, as the wife of Cleomenes the Syracusan, a woman of noble birth, and the wife of Aeschrion, born to high rank, endured it with outrage that the daughter of Isidorus the mime had come into their company. But that Hannibal now, who thought that in his army there ought to be a competition of excellence, not birth, so loved this Tertia, that he transported her with him out of the province.

22 On Lais II, see McClure (2003) 55; 118.

23 See also 2 Verr. 3.34.78; 5.16.40. 
As part of his general character assassination against Antony in the Philippics, Cicero sneers that Antony spent his dissolute youth with his mentem and his mentum, his mind and his chin, in the laps of mime actresses (Cic. Phil. 13.24):

equidem negare non possum a Caesare Hirtium ornatum, sed illa ornamenta in virtute et in industria posita lucent. tu vero qui te ab eodem Caesare ornatum negare non potes, quid esses, si tibi ille non tam multa tribuisset? ecquo te tua virtus provexisset, ecquo genus? in lustris, popinis, alea, vino tempus aetatis omne compsuisses, ut faciebas, cum in gremiis mimarum mentum mentemque deponeres.

Indeed, I cannot deny that Hirtius was honored by Caesar, but such honors shine forth when they are bestowed upon worth and hard work. You, in fact, who cannot deny that you were honored by the same Caesar, what would you be, if Caesar had not given you so much? Where would your worth and your birth have gotten you? You would have spent your entire life in brothels, in cook-shops, in dice, in wine, as you used to do when you were laying your chin and your mind in the laps of actresses.

Cicero is not our only source for Roman attitudes about mimae. Horace refers to mime actresses as safe (but not respectable) sexual outlets for young men who do not want to risk committing adultery with other men's wives (Hor. Sat. 1.2. 55-59):

ut quondam Marsaeus, amator Originis ille,

qui patrium mimae donat fundumque Laremque,

'nil fuerit mi' inquit 'cum uxoribus umquam alienis.'

verum est cum mimis, est cum meretricibus, unde

fama malum gravius quam res trahit.

Just as Marsaeus, the lover of Origo,

He who gives his estate and his household gods to a mima,

Says 'I don't have any dealings with other men's wives.'

It is true that he does have dealings with mimae, with prostitutes, from which

His reputation suffers more than his estate.

Mimae and meretrices, mime actresses and prostitutes, are equated in line 58. They are depicted as legal but disreputable sexual outlets. ${ }^{24}$ In one of his satires, Juvenal invokes the spectre of being a member of a mime troupe as a fate worse than death (Juv. 8.196-97): ${ }^{25}$

24 See discussion in Richlin (1992) 174-77; she notes at 176 that the warning scenes of lovers being chased off by angry husbands in this poem 'owe their theatrical force to mime'.

25 McCullough (2008) 205 argues that Juvenal exhibits the same class snobbery in his sixth satire, when he rails against the elite woman training to be a gladiator (6.246-67); she has betrayed both her sex and her station. See also Coleman (2000) 497. 
mortem sic quisquam exhorruit, ut sit

zelotypus Thymeles, stupidi collega Corinthi?

Did anyone ever fear death so much that he would be

The jealous husband of Thymele, or the colleague of the fool Corinthus?

The zelotypus and the stupidus were stock mime characters, as was the adulterous wife. ${ }^{26}$ In this passage, Juvenal names Thymele as a mima who played the adulterous wife. In another satire, Juvenal refers to Thymele as having been 'handed over' (summissa) to one man by another as a bribe (Juv. 1.30-36):

difficile est saturam non scribere, nam quis iniquae

tam patiens urbis, tam ferreus, ut teneat se,

causidici nova cum lectica veniat Mathonis

plena ipso, post hunc magni delator amici

et cito rapturus de nobilitate comesa

quod superest, quem Massa timet, quem munere palpat

Carus et a trepido Thymele summissa Latino?

It is hard not to write satire! For who could be so enduring of This wretched city, so hardened, that he could contain himself, When the new litter approaches of the lawyer Matho,

Full of himself, and after him the informer against his noble patron

Who quickly will seize what remains from our plundered nobles,

Whom Massa fears, whom Carus coaxes

With a bribe, and to whom Thymele was handed over by quaking Latinus?

As an actress, Thymele is presumed to be sexually accessible to any man; she is a valuable bribe, a piece of property. In a neat bit of circular logic, the cultural justification for assigning actors to the infamis status category is their immoral behavior, and then their infamis status is cited as evidence of their immoral behavior. Prostitutes, of course, were also infamis.

According to some accounts, mime actresses were known for baring more than their heads while performing. By $173 \mathrm{BC}$, the annual festival of the goddess Flora in Rome, the Ludi Florales or Floralia, was officially given over mostly to mime performance. ${ }^{27}$ An anecdote from Valerius Maximus affirms the connection between mime, specifically mime actresses, and the Floralia. Cato the Younger, who had a reputation for traditionalism like his great-grandfather Cato the Censor's, attended the Floralia at some point during the mid-first century BC but

26 Panayotakis (2010) 31; Webb (2008) 96; 105-07; Barton (1993) 139; Fantham (1986) 54; Reynolds (1946).

27 Ov. Fast. 5.327-328; Plin. HN 18.69.286; Tsitsiridis (2011) 213; Wiseman (1999) 196; Fantham (1989) 155. 
discovered that the rest of the audience would prefer it if his inhibiting presence were not there (Val. Max. 2.10.8):

eodem ludos Florales, quos Messius aedilis faciebat, spectante populus ut mimae nudarentur postulare erubuit. quod cum ex Favonio amicissimo sibi una sedente cognosset, discessit e theatro, ne praesentia sua spectaculi consuetudine impediret.

In the same place the people were watching the Floralia, which Messius was producing as aedile, but they were embarrassed to demand that the mime actresses strip. When [Cato] learned this from his good friend Favonius, who was sitting with him, he left the theatre so that his presence would not prevent the customary show.

This anecdote has often been cited as evidence that mime actresses usually performed stripteases, ${ }^{28}$ along with the story of Theodora's routine with the geese in Procopius' sixth-century CE Secret History. (Procopius claims that one of the future empress Theodora's mime routines involved stripping down to her panties, lying on her back, and allowing trained geese to peck barley grains off of her nearly-nude body. ${ }^{29}$ ) Webb has noted, however, that these two anecdotes constitute our only specific mentions of stripping or nudity as a regular part of mime performance. ${ }^{30}$ Regardless of how frequently striptease was part of mime actresses' performances, their reputations were permanently associated with the infamia of their occupation.

So it seems quite possible that male spectators of mime performances assumed that the women performing were as promiscuous and immoral as the stereotypical adulteress characters they played unmasked. The actress' lack of mask would have encouraged the impulse to conflate the actress with the role, as it presented the illusion of authenticity or naturalness or realness to the spectators. The lack of scripts, at least for improvised mimes, and the lack of a stage, for mimes performed in the streets (or in dining rooms), might have added to that sense of 'realness'. At the same time, watching a woman or women perform in mime may have denaturalized traditional masked, scripted drama. A male actor dressed as Phaedra, with his full-head mask, man's voice, and fully robed male body, might have come across differently to a spectator who had seen an unmasked archimima perform the 'jealous mistress' mime, for example. A male actor dressed as Iphigenia might have come across differently to a spectator who had seen an unmasked archimima perform the 'Charition mime,' with its farting fool and chorus of rowdy 'Indian' women. It is

28 Panayotakis (2010) 7; Wiseman (1999) 197; Barton (1993) 169 n. 111; Beacham (1991) 129.

29 Procop. Anecd. 9.20-23; see Potter (2015) 27; Webb (2008) 5-6.

30 Webb (2008) 100-101. See also Hov (2015) 139-140. 
fascinating that mime coexisted with traditional tragedy and comedy for quite some time. The symbolic (and perhaps literal) nakedness of mime actresses could be taken as a comic critique of the excessive trappings and smothering artifice of traditional drama.

On the other hand, many mime actresses used stage names, which reintroduces the idea of playing a character, or creating distance between performer and spectator. Some mime actresses' names that have come down to us from literary or epigraphic sources are very clearly stage names, such as Dionysia, Thymele ('Stage'), Emphasis ('Outward appearance, presentation'), Phoebe ('Radiant,' or perhaps a reference to Artemis), Eucharis ('Graceful'), Thalassia ('Ocean'), Arete ('Excellence'), Ecloga ('Eclogue'), and on the Latin side Arbuscula ('Shrub' - she was supposedly very short and very witty). Other known names of mime actresses are less certainly stage names, such as Bassilla (perhaps 'Queen') or Helladia (perhaps 'Girl from Hellas'). ${ }^{31}$ I should note that it is difficult to guess a mima's ethnic origin from her stage name, in the case of a name like Dionysia, especially when performers traveled widely and, it seems reasonable to speculate, many were bilingual. ${ }^{32}$ Bassilla, for example, may have had the full name Julia Bassilla; her funeral inscription is in Homeric-style Greek, and she was buried in Aquileia, in far northeastern Italy. ${ }^{33}$ Stage names do not seem to have been as common among male mime actors. The male mime actor who commissioned Bassilla's tombstone was named Herakleides. Tertia, Verres' girlfriend, was the daughter of a mime actor named Isidorus. ${ }^{34}$ Latinus frequently performed alongside Thymele. ${ }^{35}$ One male mime actor who may have used a stage name was Protogenes ('Firstborn'), from the early third century BC. ${ }^{36}$ Male actors in other, more prestigious genres seem to have performed under their real

31 Panayotakis (2010) 16 agrees that Eucharis, Ecloga, Cytheris, and Thalassia were stage names. On Ecloga, see also Höschele (2013) 37 and n. 3. Graf (1991) 48 notes that Dionysia is clearly a stage name. See also Sifakis (1966) 272.

32 On bilingualism (and possibly trilingualism) among performers in Republican Italy, see Rawson (1985) 101-104. On ethnicities vs. names of actors, Rawson (102-103 and n. 32) notes the case of an actor named Cannutius, whom Plutarch (Brut. 21.3) describes as a Greek with an Italian name.

33 IG XIV 2342; see Webb (2008) 22; 45-46; 94; 111; Lada-Richards (2007) 30; Prauscello (2004); Webb (2002) 301; Csapo/Slater (1995) 377.

34 Cic. 2 Verr. 3.34.78; 5.12.31; 5.16.40; see Panayotakis (2006) 134; Wiseman (1998) 71; Garton (1964) 239.

35 Reynolds (1946) 82 and n. 2.

36 Panayotakis (2010) 16; 23-24. 
names: on the Greek side, for example, we know of fourth-century BC tragic actors named Polos, Theodoros, and Thettalos; a fifth-century BC comic actor named Kallipides; ${ }^{37}$ on the Roman side, the late Republican comic actor Roscius and the tragic actor Aesopus. ${ }^{38}$ To what extent did these mime actresses' clearly assumed names undermine the audience's impression that they were watching real, authentic women performing without masks? Did mimae adopt these stage names, at least in part, to create some distance between themselves and the roles they played? Was the stage name the mask?

Acting was a socially and legally stigmatized occupation in the Roman world. Actors were legally classified as infamis persons, along with prostitutes, gladiators, pimps, and gladiator-trainers. ${ }^{39}$ Greek mimes performing in Roman-controlled territories would encounter this sense of stigma from their audiences, even if acting was less stigmatized in their native Greece. Infamis occupations had in common that their practitioners made a living from the display and use of their own or others' bodies. As it happens, gladiators also used stage names; they adopted names that emphasized either their ferocity, like Achilles, Tiger, or Killer, or their sex appeal, like Adonis or Hermes. Female gladiators, doubly stigmatized, fought under names like Amazonia or Achilleia. ${ }^{40}$ In thinking about who uses stage names and why, I would like to explore a modern comparandum briefly.

There are a number of modern occupations whose practitioners use stage names: some actors and pop singers do, on the more respectable end of the performance spectrum, as well as virtually all rappers, professional wrestlers, drag queens, strippers, porn stars, and prostitutes. Stephanie Clifford, for example, the porn star who broke her nondisclosure agreement with Donald Trump to reveal that they had an affair while he was married to Melania Trump, performs and directs under the stage name Stormy Daniels. As the sociologist Erving Goffman observed decades ago in his study Stigma: Notes on the Management of Spoiled Identity, people in socially stigmatized occupations often adopt stage names as one strategy to 'manage' (that is, contain) the secret of what they do for a living from those they do not wish to know, such as family members and

37 On Kallipides, see Vespa in this volume, pp. 203-205.

38 Rawson (1985) 112 provides a list of Republican Roman male actors whose names seem to reflect regional origins in Italy outside Rome; none of them sounds like a stage name. Garton (1964) 239, however, lists several plausible Greek and Roman stage names of male actors, without specifying the genres in which they performed.

39 French (1998) 296-99; Edwards (1993) 123-26.

40 McCullough (2008) 199; Coleman (2000) 487; Ewigleben (2000) 127 and fig. 137; Robert (1971) 297-301; Sifakis (1966) 272. 
neighbors. ${ }^{41}$ In her excellent monograph G-Strings and Sympathy: Strip Club Regulars and Male Desire, Katherine Frank analyses male spectators at strip clubs from the perspectives of both a sociologist and a stripper, as she supported herself through graduate school in sociology by stripping. She notes that every stripper she worked with adopted a stage name, in order to create some distance between their onstage persona and their 'real' identity, often for the purposes of concealing the nature of their work from family or friends. Some strippers had a second stage name ready to reveal to regular customers who wanted to 'get backstage,' to learn something 'real' about the strippers they found appealing - to gain some sort of intimacy. ${ }^{42}$ Other studies of strippers have also emphasized the use of stage names as a way of creating a bit of distance between their stripper personas and their 'real selves'. Thompson et al. describe how quickly strippers could move between their onstage (stage name) persona and their offstage (real name) identity, observing that when strippers were being interviewed by a sociological researcher in between dances in the strip club, they would cover their breasts as they talked in the third person about their work as 'Angel' or 'Cheyenne':

Who am I kiddin'? That was Angel talkin'. Hell, I'm a mother. I shouldn't even be in a place like this.

When I go out there on that stage I quit being me and just start being Cheyenne. I guess you could say Cheyenne is my wild side.

Then, when the interview was over, the strippers would uncover themselves, signaling the resumption of their stage personas and stage names, and leave the interviewer in order to mingle with customers again. ${ }^{43}$

There is some evidence that mime actresses in the ancient world felt defensive about their stigmatized occupation. The tombstones of Eucharis and Bassilla feature elaborate inscriptions emphasizing their skill. Eucharis is called docta and erodita on her first century BC epitaph (docta, erodita omnes artes virgo), 'trained' or perhaps 'learned'. Her epitaph asserts that she was 'the first [woman] to appear on the Greek stage before the people' (Graeca in scaenica prima populo apparui) (CIL 6.10096): ${ }^{44}$

41 Goffman (1963).

42 Frank (2002) 192-193. The customer's impulse to ask a stripper for her real name is apparently common enough that a second stage name is a common stratagem.

43 Thompson/Harred/Burks (2003) 565-566.

44 See Rawson (1985) 102 n. 31. 


\author{
Eucharis Linciniae \\ docta erodita omnes artes virgo vixit an XIIII \\ heus oculo errante quei aspicis leti domus \\ morare gressum et titulum nostrum perlege \\ amor parentis quem dedit natae suae \\ ubei se reliquiae conlocarent corporis \\ heic viridis aetas cum floreret artibus \\ crescent et aevo gloriam conscenderet \\ properavit hora tristis fatalis mea \\ et denegavit ultra veitae spiritum \\ docta erodita paene musarum manu \\ quae modo nobilium ludos decoravi choro \\ et Graeca in scaenica prima populo apparui \\ en hoc in tumulo cinerem nostri corporis \\ infistae parcae deposierunt carmine \\ stadium patronae cura amor laudes decus \\ silent ambusto corpore et leto tacent \\ reliqui fletum nata genitori meo \\ et antecessi genita post leti diem \\ bis hic septeni mecum natales dies \\ tenebris tenentur ditis aeterna domu \\ rogo ut discedens terram mihi dicas levem
}

Eucharis Liciniae

Educated and trained in all the arts; a girl who lived 14 years

You there, as you look upon the house of death with a wandering eye, slow your step and carefully read our inscription

which a father's love gave to his daughter

where the remains of her body are buried.

Just as my young life was blossoming and my skills

were growing and in time was ascending to glory,

the mournful ordained hour rushed upon me

and denied me any further breath of life.

I was educated and trained almost as if by the hand of the Muses.

I adorned the games of the nobles in a chorus,

and I first appeared before the people in a Greek play.

But now in this tomb the hostile Fates

have placed the ashes of my body along with a poem.

Devotion to a female patron, effort, love, praise, beauty

are silenced by my burned body and stilled by my death.

A daughter, I left behind weeping for my father,

and I preceded him in the day of my death, although born after him.

Now my fourteenth birthday is observed here

in the shadows, in the ageless house of Death.

I ask that upon departing you tell the earth to lie lightly upon me. 
Bassilla's third century CE epitaph says that she displayed 'every kind of skill in

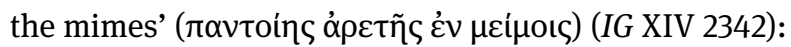

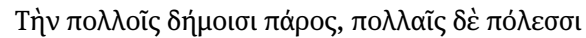

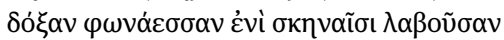

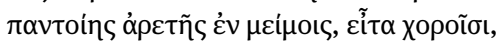

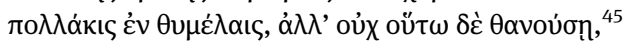

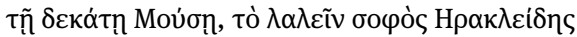

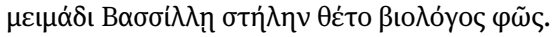

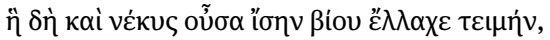

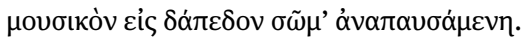

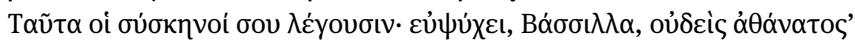

[To the woman,] Formerly in many towns and many cities having resounding fame onstage for every kind of excellence in mime, and then in dances, To her having died, often onstage, but never in that way, To her, the tenth Muse, Herakleides wise in babbling, A man and an actor, erected this stele to the mime Bassilla. But she even being dead has obtained an equal honor as in life, Resting her body in the Muses' ground.

These things her fellow actors say to her: Farewell, Bassilla, no one is immortal!

These epitaphs' emphasis on training and skill, their mentions of prestigious contests and elite audiences, their references to the Muses, all push back against acting's disreputable status.

In the Satires, Horace says that it is enough for him if Maecenas alone applauds his work, just as 'the courageous actress Arbuscula' said about the members of the equestrian class when she was hissed by the populace (Hor. Sat. 1.10.76-77):

nam satis est equitem mihi plaudere, ut audax, contemptis aliis, explosa Arbuscula dixit

It is enough for me to please an equestrian, just as the bold Arbuscula said, having been hissed by the despicable crowd

Appeals to the educated elite, whether through emphasizing training, skill, performing in Greek plays (in Italy), or winning favour with the equestrians (even if not with the plebs) are all ways of staking a claim to a certain kind of respectability.

45 Taking Prauscello's (2004) 'metatheatrical' reading of this line: she 'died' onstage many times before dying in real life (but not in the way her characters died onstage). The previous

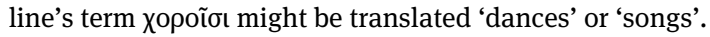


For women who feel overly exposed, the stage name is a different kind of covering. It creates a theatrical persona, even in an improvised art form, as mime could be, or a nonverbal art form, as stripping usually is. The persona bears the brunt of the male gaze, and the stigma associated with exposing oneself to that gaze. ${ }^{46}$ The unmasked mime actress promised to reveal all, to unmask Greco-Roman theatrical conventions in a comical and exciting shedding of pretension, to uncover the real body of a real woman before the public gaze but she hid herself behind a stage name, as if behind a pair of sunglasses, or a professional detachment. In his essay on the Parisian striptease, Roland Barthes asserts that when professional striptease dancers remove all their clothes, they 'wrap themselves in a miraculous ease which constantly clothes them, affords them the icy indifference of skilful practitioners haughtily taking refuge in the certitude of their technique: their knowledge clothes them like a garment'. ${ }^{47}$ What was the knowledge that mime actresses clothed themselves in? The knowledge that theatre is never wholly fake or wholly real; that the real woman, performing before a crowd of men who were used to seeing men in female masks, was another theatricalized woman. Mime actresses functioned metatheatrically; their performances called attention to the conventions and artifice of traditional Greco-Roman masked, all-male drama. They accomplished this metatheatrical critique in a conventionally theatrical way, however, by performing a role, living up to their stage name, becoming 'Dionysia' or 'Arbuscula', 'Angel' or 'Cheyenne'.

46 Hov (2015) 140-142 also connects the male gaze to the infamy of specifically female performance in Greco-Roman Antiquity.

47 Barthes (2013) 167. 
